\title{
BMJ Global Health Big food and the World Health Organization: a qualitative study of industry attempts to influence global- level non-communicable disease policy
}

\author{
Kathrin Lauber (D , , ${ }^{1}$ Harry Rutter (D) , ${ }^{2}$ Anna B Gilmore ${ }^{1}$
}

To cite: Lauber K, Rutter H, Gilmore AB. Big food and the World Health Organization: a qualitative study of industry attempts to influence global-level non-communicable disease policy. BMJ Global Health 2021;6:e005216. doi:10.1136/ bmjgh-2021-005216

\section{Handling editor Eduardo Gómez}

- Additional supplemental material is published online only. To view, please visit the journal online (http://dx.doi.org/10. 1136/bmjgh-2021-005216)

Received 31 January 2021 Revised 8 April 2021 Accepted 25 April 2021

Check for updates

(c) Author(s) (or their employer(s)) 2021. Re-use permitted under CC BY. Published by BMJ.

${ }^{1}$ Tobacco Control Research Group, Department for Health, University of Bath, Bath, UK ${ }^{2}$ Department of Social and Policy Sciences, University of Bath, Bath, UK

Correspondence to

Kathrin Lauber;

k1580@bath.ac.uk

\section{ABSTRACT}

Introduction There is an urgent need for effective action to address the over 10 million annual deaths attributable to unhealthy diets. Food industry interference with policies aimed at reducing noncommunicable diseases (NCDs) is widely documented at the national level but remains under-researched at the global level. Thus, this study explores how ultraprocessed food industry actors have attempted to influence NCD policy at WHO.

Methods A combination of inductive and deductive thematic coding of internal industry documents, academic literature and interviews with key informants from international organisations and global civil society was used to identify action-based strategies ultraprocessed food industry actors employ to influence global-level policy.

Results Ultra-processed food industry actors have attempted to influence WHO and its policies through three main action-based strategies: coalition management, involvement in policy formulation, and information management. Coalition management includes the creation and use of overt alliances between corporations-business associations-and more covert science-focused and policy-focused intermediaries, the hiring of former WHO staff and attempted co-option of civil society organisations. Industry involvement in policy formulation is operationalised largely through the lobbying of Member States to support industry positions, and business associations gaining access to WHO through formal consultations and hearings. Information management involves funding and disseminating research favourable to commercial interests, and challenging unfavourable evidence.

Conclusion We provide novel insights into how ultraprocessed food industry actors shape global-level NCD policy and identify a clear need to guard against commercial interference to advance NCD policy. In their approach, the political behaviour of multinational food corporations bears similarities to that of the tobacco industry. Increased awareness of, and safeguarding against, commercial interference at the national as well as the global level have the potential to strengthen the crucial work of WHO.

\section{Summary box}

What is already known?

- A growing body of evidence suggests that the ultraprocessed food industry (UPFI) has consistently engaged in political activities to delay, weaken or prevent public health regulation, using strategies such as direct lobbying, influence through seemingly independent third parties and the production or strategic use of evidence.

- UPFI political activity at the global level remains under-researched; thus, we explore action-based strategies of UPFI actors in interaction with noncommunicable disease (NCD) policy at WHO, complementing a recent investigation of arguments and framing in the same policy arena.

What are the new findings?

- UPFI actors have attempted to shape WHO policy on NCDs by (1) establishing and working through supportive coalitions while seeking to co-opt civil society groups, (2) harnessing or seeking access to WHO through formal and informal routes and (3) strategically disseminating favourable information.

- There are similarities with the tobacco industry's behaviour in opposition to WHO's efforts to advance tobacco control, although much less data are available for the food industry to date.

What do the new findings imply?

- Better safeguards against commercial interference and conflicts of interest at the global level as well as the national level have the potential to support WHO's leading role in action towards better diets.

\section{INTRODUCTION}

Unhealthy diets are a major risk factor for noncommunicable diseases (NCDs) such as heart disease, type 2 diabetes and cancer. ${ }^{1}$ Despite ongoing calls for action on obesity and dietary NCDs, no country has successfully lowered obesity rates between 1990 and 2019. ${ }^{2}$ Barriers to progress include opposition of powerful commercial actors, notably the multinational ultra-processed food and beverage industry 
(UPFI), ${ }^{3}$ which we define as corporations involved in the manufacture or sale of ultra-processed foods and sugar-sweetened beverages. A growing body of evidence documents how these actors have attempted to oppose regulation at the national level, for instance, through direct and indirect lobbying of decision-makers, the creation and use of seemingly independent third parties and influence on the production and use of science. ${ }^{4-7} \mathrm{We}$ use the term 'corporate political activity' to describe such behaviour. Originally developed by management scholars to describe 'corporate attempts to shape government policy in ways favourable to the firm, ${ }^{8}$ it has since been adopted by public health researchers using a critical lens to understand industry efforts to oppose regulation. ${ }^{9}{ }^{10}$ In the case of the UPFI, such political activities have been identified in low-income and middle-income countries ${ }^{711-15}$ as well as high-income countries, ${ }^{4516-18}$ but as yet, there is little empirical evidence at the global level.

In response to calls for stronger leadership from international organisations (IOs) to curb the devastating health and economic ${ }^{19}$ impacts of NCDs, the United Nations (UN) held their first high-level meeting (HLM) on NCDs in 2011, assembling heads of state and UN agencies to discuss action towards better prevention and treatment. ${ }^{20}$ This was followed by two subsequent HLMs in $2014^{21}$ and $2018,{ }^{22}$ with a fourth scheduled for 2025 . As the UN agency responsible for public health, WHO plays a key role in coordinating global efforts to prevent NCDs. Its power to set international rules which can restrict private sector activities, like the Framework Convention on Tobacco Control (FCTC), ${ }^{23}$ has been described as 'political dynamite..$^{24}$ Although WHO has published technical guidance on obesity and dietary NCDs, Member State-led political decisions remain unambitious (key developments in table 1). ${ }^{25}$ Public health advocates largely greeted the political declaration of the third $\mathrm{HLM}^{22}$ and what were intended as 'bold recommendations' from the WHO independent high-level commission ${ }^{26}$ to the HLM with disappointment. The declaration was criticised for its weak language on NCD interventions and financing ${ }^{2728}$ and the commission's report for producing recommendations weaker than existing WHO guidance after a US representative 'torpedoed' ${ }^{29}$ efforts to include a recommendation to tax sugar-sweetened beverages..$^{30} 31$ UPFI representatives, on the other hand, welcomed both documents, lauding calls for public-private collaboration in particular. ${ }^{29} 32$

Another point of contention is WHO's contrasting approach to the unhealthy commodity industries which drive NCDs and have a history of impeding policy progress at national level. ${ }^{33}$ The agency has a strict policy of non-engagement with the tobacco industry as mandated by Article 5.3 of the FCTC, ${ }^{23}$ but its Framework of Engagement with Non-State Actors (FENSA) ${ }^{34}$ has been described as an open door rather than a fence for other commercial actors, including the UPFI. ${ }^{35}$ The new official relations status-which business associations, philanthropic foundations and non-governmental organisations (NGOs) can apply for-is not a requirement for WHO to engage with a non-state actor but provides privileged access, for instance, allowing participation in WHO governing bodies meetings. ${ }^{36}$ Welcomed by the private sector when it was adopted in 2016 after 4 years of negotiation with Member States, FENSA was again deemed insufficient by public health advocates. ${ }^{37}$

In light of the lack of progress in addressing a major cause of ill health globally, there is an urgent need to better understand how the UPFI attempts to influence global-level NCD policy. ${ }^{38}$ We aim to address this gap by harnessing conceptual developments from tobacco control research, which were significantly advanced by the release of millions of internal tobacco industry documents through litigation in the 1990s. ${ }^{39}$ These documents offer unique and detailed insights into corporate policy influencing strategies in a way which has not hitherto been possible for the UPFI: in January 2021, the Tobacco Industry Documents Archive ${ }^{40}$ hosted 12220 370 documents, whereas its food industry counterpart only contained $131865 .^{41}$ An evidence-based model of tobacco industry political activity, the Policy Dystopia Model $(\mathrm{PDM}){ }^{10}$ has been developed using two systematic reviews of tobacco industry document research. It categorises corporate political activity into argument-based and action-based strategies, showing how they work collectively to construct and disseminate a narrative that regulatory policies will fail and lead to undesirable consequences. The PDM presents two hierarchical taxonomies of instrumental (action-based) and discursive (argumentbased) strategies with the respective subcategories of techniques and arguments. Researchers have successfully applied the PDM to study political activities of the UPFI and other industries at the national level, demonstrating its applicability beyond tobacco control. ${ }^{13}{ }^{14} 42-44$ Our study harnesses the PDM to examine UPFI instrumental strategies at the global level. In doing so, it builds on our recent work which examined the UPFI's discursive strategies in WHO consultations. ${ }^{45}$ The study aims to:

- examine UPFI political activity—specifically its instrumental strategies-aimed at WHO.

Additionally, we seek to explore how this differs with the better documented tobacco industry political activities against WHO's public health efforts, ${ }^{46-48}$ and how public health actors explain these differences.

\section{METHODS}

We drew on multiple sources to map the instrumental strategies UPFI actors use, focusing on post-2000 policy developments around obesity and dietary NCDs at WHO headquarters. UPFI actors were defined as including corporations involved in the manufacture of ultraprocessed products, forming a key part of their supply chain, or holding a financial interest in the sale of these products, including ingredient supply and processing, fast food restaurant organisations, and retail. ${ }^{45}$ 
Table 1 Key WHO/UN publications and events relating to obesity and dietary NCDs from 2000 onwards

\begin{tabular}{|c|c|c|}
\hline Year & Title & Detail \\
\hline 2000 & $\begin{array}{l}\text { Global strategy for the } \\
\text { prevention and control of } \\
\text { NCDs }^{135}\end{array}$ & The strategy was adopted at the 53rd World Health Assembly (WHA). \\
\hline 2003 & $\begin{array}{l}\text { Diet, nutrition and the } \\
\text { prevention of chronic diseases } \\
(\text { TRS } 916)^{136}\end{array}$ & $\begin{array}{l}\text { Report of the joint WHO/FAO expert consultation with Member States, UN } \\
\text { agencies, civil society and the private sector. }{ }^{137} \text { It includes a recommendation } \\
\text { to limit free sugar intake to } 10 \% \text { of calorie intake. }\end{array}$ \\
\hline 2004 & $\begin{array}{l}\text { Global strategy on diet, } \\
\text { physical activity and health }\end{array}$ & $\begin{array}{l}\text { The strategy was mandated by Member States at the 55th and endorsed at } \\
\text { the } 57 \text { th WHA. After opposition from industry and some Member States to TRS } \\
916 \text {, reference to the expert report and its key recommendations was dropped } \\
\text { from the final strategy. }\end{array}$ \\
\hline 2008 & $\begin{array}{l}2008-2013 \text { action plan for } \\
\text { the global strategy for the } \\
\text { prevention and control of }\end{array}$ & $\begin{array}{l}\text { The action plan draws on the } 2000 \text { global strategy and the } 2004 \text { global strategy, } \\
\text { setting out six key objectives. It was endorsed at the } 61 \text { st WHA. }\end{array}$ \\
\hline
\end{tabular}
prevention and control of $\mathrm{NCDs}^{138}$

$\begin{array}{ll}2010 & \begin{array}{l}\text { Set of recommendations on } \\ \text { the marketing of foods and } \\ \text { non-alcoholic beverages to } \\ \text { children }\end{array} \\ 2011 & \begin{array}{l}\text { WHO global forum: addressing } \\ \text { the challenge of NCDs }\end{array} \\ 2011 & \begin{array}{l}\text { First UN HLM on NCDs: } \\ \text { political declaration of the first } \\ \text { HLM on NCDs }\end{array} \\ 2012 & \begin{array}{l}\text { A framework for implementing } \\ \text { the set of recommendations } \\ \text { on the marketing of foods and } \\ \text { non-alcoholic beverages to } \\ \text { children }\end{array}\end{array}$

2013 Global action plan for the
prevention and control of NCDs
$2013-2020^{1}$

The 2013-2020 action plan, replacing the 2008-2013 action plan, was adopted The set of evidence-based recommendations was endorsed at the 62nd WHA and followed up by a mandate to develop technical guidance to support the implementation of the recommendations.

In the lead-up to the 2011 HLM, the global forum was held in Moscow as a multistakeholder forum which brought together Member States and a range of non-state actors, including the private sector.

The political declaration of the first HLM on NCDs was adopted at the 66th UN General Assembly.

Technical guidance on the implementation of the set of recommendations was provided following a mandate by the 62nd WHA.

at the 66th WHA. It sets nine voluntary targets, including a $25 \%$ reduction in premature mortality from NCDs by 2025 , and provides policy recommendations to achieve these.

2014 Rome declaration on nutrition (and framework for action) $)^{142143}$

Outcome documents of the Second International Conference on Nutrition (ICN2), which was convened jointly by WHO and FAO, and attended by 'nearly 100 (representatives) from the business community'. ${ }^{144}$

$\begin{array}{ll}2014 & \begin{array}{l}\text { Second UN HLM on NCDs: } \\ \text { outcome document of the } \\ \text { second HLM on NCDs }\end{array} \\ 2015 & \begin{array}{l}\text { Guideline: sugars intake for } \\ \text { adults and children }\end{array}\end{array}$

The second HLM took place to review and assess progress towards NCD targets. The outcome document was adopted at the 68th UN General Assembly.

Part of the effort to reach targets set by the 2013-2020 action plan and based on a review of the scientific evidence and expert consultation, the new guidelines recommend a reduction of daily intake of free sugars to $<10 \%$ of total energy intake, with a reduction to below $5 \%$ recommended for further health benefits.

\begin{tabular}{lll}
2016 & $\begin{array}{l}\text { Sustainable Development } \\
\text { Goals (SDGs) }\end{array}$ & $\begin{array}{l}\text { Ratified in 2015, the 17 SDGs replaced the Millennium Development Goals on } 1 \\
\text { January 2016. SDG } 3 \text { is focused on health, but many others relate to food and } \\
\text { nutrition. }\end{array}$ \\
2016 & $\begin{array}{l}\text { Fiscal policies for diet and the } \\
\text { prevention of NCDs }\end{array}$ & $\begin{array}{l}\text { Based on a technical meeting held on 5-6 May 2015 in response to the } \\
\text { increasing number of Member State requesting guidance on fiscal policies for } \\
\text { health. The report supports sugar-sweetened beverage taxes. }\end{array}$ \\
\hline $\begin{array}{l}\text { Report of the commission on } \\
\text { ending childhood obesity }\end{array}$ & $\begin{array}{l}\text { The commission was established in 2014 by the Director General, and its final } \\
\text { report welcomed at the 69th WHA in 2016. The process leading up to the report } \\
\text { included consultation with the private sector and civil society. }\end{array}$ \\
\hline
\end{tabular}




\begin{tabular}{|c|c|c|}
\hline Year & Title & Detail \\
\hline 2017 & $\begin{array}{l}\text { Montevideo roadmap } 2018- \\
2030 \text { on NCDs as a sustainable } \\
\text { development priority }{ }^{149}\end{array}$ & $\begin{array}{l}\text { The roadmap is the outcome document of the WHO global conference on } \\
\text { NCDs, a high-level event. The process leading up to the conference included a } \\
\text { public consultation. }\end{array}$ \\
\hline 2017 & $\begin{array}{l}\text { Tackling NCDs: 'best buys' } \\
\text { and other recommended } \\
\text { interventions for the prevention } \\
\text { and control of NCDs }\end{array}$ & $\begin{array}{l}\text { Appendix } 3 \text { of the } 2013-2020 \text { action plan was endorsed at the } 70 \text { th WHA with } \\
\text { resolution WHA70.11. It identifies a menu of policy options for Member States, } \\
\text { part of which is the set of cost-effective best buys. Italy and the USA did not } \\
\text { endorse the updated set of best buys and other recommended interventions, } \\
\text { dissociating themselves from the relevant paragraph of WHA70.11. }{ }^{151}\end{array}$ \\
\hline 2018 & $\begin{array}{l}\text { Time to deliver: report of the } \\
\text { WHO independent high-level } \\
\text { commission on } \mathrm{NCDs}^{26}\end{array}$ & $\begin{array}{l}\text { The first report of the high-level commission on NCDs, tasked with advising the } \\
\text { WHO Director General on accelerating progress against NCDs, was published } \\
\text { following a public consultation and provided six recommendations. It was } \\
\text { welcomed at the 73rd UN General Assembly. }\end{array}$ \\
\hline 2018 & $\begin{array}{l}\text { Third UN HLM on NCDs: } \\
\text { political declaration of the third } \\
\text { HLM on NCDs }\end{array}$ & $\begin{array}{l}\text { Adopted at the } 73 \text { rd UN General Assembly, following the third HLM on NCDs, } \\
\text { the political declaration reaffirms commitments to address NCDs globally and } \\
\text { schedules the next HLM for } 2025 \text {. }\end{array}$ \\
\hline 2019 & $\begin{array}{l}\text { Final report of the WHO } \\
\text { independent high-level } \\
\text { commission on NCDs: it is time } \\
\text { to walk the talk }{ }^{152}\end{array}$ & $\begin{array}{l}\text { The second and final report of the WHO independent high-level commission } \\
\text { on NCDs delivers a number of recommendations to WHO, including scaling up } \\
\text { private sector engagement. }\end{array}$ \\
\hline
\end{tabular}

FAO, Food and Agriculture Organization; HLM, high-level meeting; NCD, non-communicable disease; TRS, technical report series; UN, United Nations.

\section{Data}

We triangulated key informant interviews with a review of academic literature and UPFI documents published via the Food Industry Documents Archive ${ }^{41}$ to gain a more comprehensive understanding. ${ }^{49}$

\section{Interviews}

We conducted semi-structured interviews with 16 key informants who had 3 or more years of experience in supranational NCD policymaking and had closely participated in WHO processes. Interviewees were identified through purposive and snowball sampling and approached via email. The interview schedule-developed based on authors' knowledge of the topic, reading of key literature, and the PDM-used open questions and focused probing, allowing for exploration of topics interviewees perceived as particularly relevant. ${ }^{5051}$ The lead author conducted interviews remotely $(n=13)$ or in person $(n=2)$ between October 2019 and June 2020. Four informants were current employees of an IO, 2 were former IO employees and 10 were advocates who engaged with WHO on NCD policy (table 2). Two participants were interviewed together (CS-2). Interviews lasted between 27 and $101 \mathrm{~min}$, averaging approximately an hour. If participants agreed to be recorded, the lead author transcribed the interviews. Two interviews were not audio-recorded on the participants' request, instead detailed notes were taken and approved. All interviewees provided informed consent and were fully anonymised due to the sensitive nature of the topic.

\section{Literature and document searches}

We conducted systematic searches in Web of Science, PubMed, Scopus, and Google Scholar using combinations of the following terms: food/beverage/sugar, corporate/commercial/industry, political activity/ influence/interference/involvement, lobby*, 'world health organization', 'united nations' (details in online supplemental file 1). We included pieces which were published in peer-reviewed journals after 1999 and contained concrete information on political activities (rather than arguments or market strategies) of UPFI actors described as targeting WHO in relation to NCDs. Additional literature, including source material cited and providing evidence of UPFI conduct, was identified from bibliographies of included studies. The review was initially conducted in September 2019 and updated in October 2020, identifying 21 articles, of which only 10 presented primary research (online supplemental file 2).

We searched the Food Industry Documents Archive using combinations of the terms "world health organization', 'united nations' and 'world health assembly'. Documents were included if they contained information on actual or planned UPFI activities in relation to WHO after 2000. Searches identified 16 documents which had been released through leaks, litigation or freedom of information requests (online supplemental file 2).

Targeted follow-up web searches (Google, WHO, key UPFI/third-party actor websites) were conducted to corroborate and expand on information identified from interviews, literature or documents. We only name corporations where we have supporting documentary evidence. 
Table 2 Interviews: all participants are identified through their primary role

\begin{tabular}{lll}
\hline Interviewee code & Background of interviewee(s) & Interview mode and duration \\
\hline IO-1 & Current IO employee with NCD-relevant remit & In person, 51 min \\
IO-2 & Current IO employee with NCD-relevant remit & Remotely, 44 min \\
IO-3 & Current IO employee with NCD-relevant remit & Remotely, 49 min \\
IO-4 & Current IO employee with NCD-relevant remit & Remotely, 46 min \\
Ex-IO-1 & Former IO employee/CS member & Remotely, 47 min \\
Ex-IO-2 & Former IO employee/academic & Remotely, 1 hour 11 min \\
CS-1 & CS member, previously IO & Remotely, 1 hour 3 min \\
CS-2 & Joint interview of two CS members & Remotely, not recorded \\
CS-3 & CS member/academic & Remotely, not recorded \\
CS-4 & CS member & Remotely, 27 min \\
CS-5 & CS member & Remotely, 28 min \\
CS-6 & CS member & Remotely, 1 hour 41 min \\
CS-7 & CS member & In person, 1 hour 17 min \\
CS-8 & CS member & Remotely, 46 min \\
CS-9 & CS member & Remotely, 50 min \\
\hline
\end{tabular}

CS, civil society; IO, international organisation; NCD, non-communicable disease.

\section{Analysis}

We adopted the strategies from the PDM to structure our analysis but identified techniques inductively to ensure novel insights from the global-level context are captured. When analysing UPFI documents, we followed a hermeneutic approach, starting by reading and re-reading them and carefully considering their meaning and the context in which they were produced throughout the analysis. ${ }^{52}$ During an initial reading of all data, we confirmed that the PDM was an appropriate analytical framework and made the decision that no additional strategies needed to be created.

The lead author coded interview data, internal documents, and literature in three main steps, using a combination of inductive and deductive thematic analysis ${ }^{53}$ with a latent coding approach to create a hierarchical framework of UPFI behaviour. First, individual industry actions were identified inductively as the smallest unit of analysis. They were judged relevant if they fit conceptually into one of the instrumental strategies from the PDM. Second, they were grouped into techniques based on conceptual coherence. To be recorded as such, a technique had to be supported by at least two data points and verified by documentary evidence where possible. Third, we grouped techniques into instrumental strategies from the PDM. The framework developed by the lead author was refined iteratively in discussion with the wider research team.

Analyses were conducted using NVivo V.12. ${ }^{54}$

\section{RESULTS}

We identified numerous actions which could be collapsed into 10 techniques and 3 overarching instrumental strategies which interlink and reinforce each other: coalition management, UPFI involvement and influence in policy, and information management (table 3). In this section, we present the hierarchical framework which resulted from our analysis. While we present our results through a global lens, it was clear that some attempts at influence were operationalised through the national level.

\section{Coalition management}

Our analysis suggests that the UPFI created and used multiple voices and alliances to support its positions and gain routes for access, while attempting to weaken potential opponents through co-option.

\section{Harnessing access to WHO Members States}

WHO Member States-most frequently countries in which multinational food corporations are headquartered-were highlighted as a crucial path for UPFI influence by nearly all interviewees, in internal documents and the literature. One IO employee noted: 'my experience is always that [food corporations] work through Member States, they influence, and they weaken the language. That's more [...], at country level, where they directly lobby' (IO-4). Evidence indicates that UPFI actors actively lobbied national government bodies to promote UPFI-favourable positions in WHO negotiations (IO-4, ex-IO-2, CS-4, CS-5, CS-6, CS-8, CS-9) ${ }^{55-61}$ In this context, 3 interviewees reported that the risk of influence on political documents, agreed by Member State consensus, was greater than on technical guidance based on evidence review and expert advisory groups (IO-1, ex-IO-1, CS-2). Such involvement was described as a relatively recent phenomenon: 1 interviewee with two decades of professional experience reflected: 'NCDs have really emerged over the last six years, seven years, [...]. That's where [the UPFI] started to penetrate the discourse. So, [food company] didn't really have 


\begin{tabular}{|c|c|c|c|c|c|}
\hline \multirow[b]{2}{*}{ Strategy } & \multirow[b]{2}{*}{ Definition } & \multirow[b]{2}{*}{ Technique } & \multicolumn{3}{|l|}{ Supportive evidence } \\
\hline & & & Interviews & $\begin{array}{l}\text { Internal } \\
\text { documents }\end{array}$ & Literature \\
\hline \multirow[t]{5}{*}{$\begin{array}{l}\text { Coalition } \\
\text { management }\end{array}$} & \multirow{5}{*}{$\begin{array}{l}\text { Building or managing } \\
\text { alliances with other } \\
\text { corporations or societal } \\
\text { actors to establish } \\
\text { alternative platforms for } \\
\text { arguments or routes for } \\
\text { access }\end{array}$} & $\begin{array}{l}\text { Harnessing access to } \\
\text { Member States }\end{array}$ & $\begin{array}{l}\text { IO-1, IO-2, IO-3, IO-4, ex- } \\
\text { IO- } 1 \text {, ex-1O-2, CS-2, CS-3, } \\
\text { CS-4, CS-5, CS-6, CS-7, } \\
\text { CS-8, CS-9 }\end{array}$ & $55-57153154$ & 585972 155-157 \\
\hline & & $\begin{array}{l}\text { Engaging in business } \\
\text { coalitions }\end{array}$ & $\begin{array}{l}\text { IO-2, IO-4, ex-1O-2, CS-1, } \\
\text { CS-4, CS-6, CS-7, CS-9 }\end{array}$ & 5760154 & 565859727489105 \\
\hline & & $\begin{array}{l}\text { Working through } \\
\text { science/policy } \\
\text { intermediaries }\end{array}$ & $\begin{array}{l}\text { IO-3, ex-1O-1, ex-1O-2, CS- } \\
1, \text { CS- } 2 \text {, CS- } 7 \text {, CS-8 }\end{array}$ & $\begin{array}{l}5778101102 \\
158\end{array}$ & $\begin{array}{l}1756585979808489 \\
159\end{array}$ \\
\hline & & Co-opting civil society & $\begin{array}{l}\text { IO-3, ex-1O-1, ex-1O-2, CS- } \\
5, \text { CS-6, CS-7, CS-8, CS-9 }\end{array}$ & - & 3889 \\
\hline & & Hiring former WHO staff & CS-1 & - & 89 \\
\hline \multirow[t]{2}{*}{$\begin{array}{l}\text { Involvement } \\
\text { and influence } \\
\text { in policymaking }\end{array}$} & \multirow{2}{*}{$\begin{array}{l}\text { Gaining or maintaining } \\
\text { access to, and } \\
\text { seeking representation } \\
\text { or involvement in } \\
\text { policymaking, including } \\
\text { direct lobbying of } \\
\text { policymakers }\end{array}$} & $\begin{array}{l}\text { Participating in } \mathrm{WHO} \\
\text { processes }\end{array}$ & $\begin{array}{l}\mathrm{IO}-1, \mathrm{IO}-2, \mathrm{IO}-3, \mathrm{IO}-4, \mathrm{ex}- \\
\mathrm{IO}-1 \text {, ex-IO-2, CS-1CS-4, } \\
\mathrm{CS}-5 \text {, CS-6, CS-8 }\end{array}$ & 60 & 38565859747589 \\
\hline & & $\begin{array}{l}\text { Intimidating } \\
\text { policymakers }\end{array}$ & Ex-IO-1, ex-1O-2, IO-4 & - & - \\
\hline \multirow[t]{3}{*}{$\begin{array}{l}\text { Information } \\
\text { management }\end{array}$} & \multirow{3}{*}{$\begin{array}{l}\text { Sponsoring, producing } \\
\text { or disseminating } \\
\text { favourable information } \\
\text { while suppressing and } \\
\text { undermining unfavourable } \\
\text { information }\end{array}$} & $\begin{array}{l}\text { Sponsoring or } \\
\text { disseminating } \\
\text { favourable information }\end{array}$ & $\begin{array}{l}\text { IO- } 1 \text {, ex-1O-1, ex-1O-2, CS- } \\
1, \mathrm{CS}-2\end{array}$ & 60 & 56598089159 \\
\hline & & $\begin{array}{l}\text { Challenging or } \\
\text { undermining } \\
\text { unfavourable } \\
\text { information }\end{array}$ & IO-1, CS-5 & 60 & 565859747980 \\
\hline & & $\begin{array}{l}\text { Managing own image/ } \\
\text { engaging in corporate } \\
\text { social responsibility } \\
\text { activities }\end{array}$ & IO-1, IO-2, CS-6, CS-7 & 106 & 89105107 \\
\hline
\end{tabular}

CS, civil society; IO, international organisation; UPFI, ultra-processed food industry.

much interest in the neglected diseases or infectious diseases arena' (CS-8).

Interviewees highlighted 2 Member States as particularly aligned with commercial interests: Italy and the USA. Italy has opposed guidelines for sugar and meat reduction, and front-of-pack labelling policies ${ }^{62}{ }^{63}-\mathrm{a}$ stance often positioned as defending the Mediterranean $\operatorname{diet}^{64}$ but attributed by participants to the political power the confectionery manufacturer Ferrero and other UPFI actors hold in Italy (CS-1, ex-IO-1, IO-3, IO-4). For example, Italy strongly opposed WHO's 2015 sugar guidelines, ${ }^{65}$ which included a recommendation to decrease consumption to $5 \%$ or less of total calorie intake, ${ }^{66}$ and at the 136 th WHO Executive Board meeting leading up to the publication of the guidelines called for an urgent review of WHO's technical guideline development process towards greater involvement of Member States and 'other stakeholders. ${ }^{67}$ The Italian delegation to this meeting included an 'expert' to the Ministry of Foreign Affairs who had appeared as a senior advisor to Ferrero until shortly before (CS-3, CS-8). ${ }^{6668} 69$ Notably, Italy protested against the participation of a WHO official in the EAT-Lancet Commission on Food, Planet and
Health, and WHO's decision to host the launch event, ${ }^{64} 70$ although we obtained no evidence of UPFI involvement in this.

The USA was a key player in the possibly bestdocumented case of UPFI interference with WHO policymaking. The Sugar Association and other UPFI groups mounted a concerted campaign against the 2004 Global Strategy on Diet, Physical Activity and Health, and the science underlying it. UPFI efforts focused particularly on the recommendation to restrict added sugar intake to $10 \%$ of daily energy consumption. The Sugar Association wrote to the then US Minister of Health, asking him to withdraw US funding to WHO unless the recommendation was removed. ${ }^{71}$ This prompted a US official to oppose the recommendation in a letter to WHO. ${ }^{56597273}$ Interviewees noted that the USA had continued to oppose regulatory approaches in favour of voluntary or partnership measures (IO-1, IO-2, IO-4, CS-1, CS-5, CS-6) $)^{74} 75$ and appeared aligned with UPFI interests (CS-1, CS-2, CS-5, CS-6, CS-7, CS-8, CS-9). One participant contended that a statement from the US Chamber of Commerce opposing the Trump administration's 2020 move to end its WHO membership ${ }^{76}$ signalled the industry's concern 
Box 1 The International Food and Beverage Alliance (IFBA)

Registered in Geneva, IFBA was founded in 2008 by the CEOs of 10 major food and non-alcoholic beverage corporations 'to support public-private partnerships to accomplish the objectives of WHO' in the area of non-communicable diseases. ${ }^{160}$ Among ultra-processed food industry associations, IFBA has been the most prolific participant in WHO consultations in recent years. ${ }^{45}$ IFBA is c0-chaired by senior executives from its member corporations, at the time of writing a Vice President of Ferrero and Mondelez International's Director of Global Public Affairs. ${ }^{161}$ Previous co-chairs include Janet Voûte, ${ }^{103}$ who was hired by Nestlé after leaving her post at WHO.

Since 2014, IFBA's acting Secretary-General is Rocco Renaldi, Founding Partner of Landmark Public Affairs, which publicly lists PepsiCo, Kellogg's, the World Federation of Advertisers and the voluntary advertising initiative EU Pledge among its clients. ${ }^{162} 163$ As of April 2021, Renaldi was also in charge of the European lobby group FoodServiceEurope. ${ }^{164}$ Previous IFBA Secretary-Generals include Delon Human, a South African doctor who has also provided consultancy services to British American Tobacco through two of his companies. ${ }^{165}$ Human was allegedly removed from his role at IFBA after his tobacco links became known to WHO. ${ }^{165}$

IFBA has consistently advocated for a close relationship between $\mathrm{WHO}$ and the food industry. For instance, it opposed a WHO tool aimed at supporting countries in safeguarding nutrition policies from conflicts of interest ${ }^{45}$ and an email leaked to the Times of India revealed efforts by IFBA to lobby Member States against the exclusion of the food industry from WHO's Framework of Engagement with NonState Actors. ${ }^{166}$

that 'without their friends in the US government trying to call the shots at WHO, they have less ability to influence the agenda at WHO' (CS-9).

\section{Business coalitions}

Formal WHO interactions with the UPFI primarily take place through business associations, ${ }^{45}$ in line with FENSA and WHO's preference to avoid association with one individual company over another (IO-2). ${ }^{34}$ A set of UPFIspecific and multi-industry business associations specialising in interacting with the UN system is discernible, ${ }^{45}$ and efforts in the obesity space are spearheaded by the International Food and Beverage Alliance (IFBA, box 1), which unites 12 food and beverage multinationals. UPFI corporations tend to be represented in multiple business associations which coordinate efforts and provide numerous routes to global policymakers. ${ }^{45}$ For instance, a delegation of US Council for International Business members, including Ferrero, met with WHO and other IOs in 2018 'to highlight American policy priorities and concerns, 77

\section{Science/Policy intermediaries}

Alongside business associations which overtly represent business interests, the UPFI has also, more covertly, attempted to influence policy through intermediary organisations or individuals at the intersection of science and policy (science/policy intermediaries (SPIs)) with significant corporate involvement or funding. SPIs include individual scientists, ${ }^{17} 78$ but predominantly involve organisations such as the International Life Sciences Institute (ILSI) (CS-2), ${ }^{79}$ the now defunct Global Energy Balance Network (ex-IO-1), ${ }^{80}$ or the International Food Information Council. ${ }^{79}$ In-depth studies of ILSI, for example, conclude that the organisation has promoted industry interests across national and global settings, while enjoying privileged access as a seemingly independent organisation. ${ }^{79} 80$ US Internal Revenue Service filings suggest that ILSI also sponsored WHO internships in 2012, 2013 and $2015 .{ }^{81-83}$ SPIs often facilitate information management (see information management section below).

Philanthropic institutions such as the Bill and Melinda Gates Foundation, among the top funders of WHO, have significant agenda-setting power in global health and can influence priorities through earmarked contributions. ${ }^{84}$ Four interviewees expressed concerns about the Gates Foundation's pro-industry stance (IO-3, ex-IO-1, CS-7, CS-8). The most recent tax return of the Bill and Melinda Gates Foundation Trust suggests that it does, for instance, have investments in a number of UPFI corporations, including PepsiCo, Coca-Cola (FEMSA and European Partners), and McDonald's, ${ }^{85}$ and has funded projects in partnership with the latter. ${ }^{84}$ Such relationships have been perceived as channels for influence by industry allies ${ }^{17}$ : ILSI's founder responded to a US official's suggestion to lobby WHO through 'Gates or Bloomberg people' with the following: 'I like the one especially about having Mr. Bill Gates help. Our Chairman knows him well. ${ }^{, 78}$

\section{Co-opting civil society}

Our analysis indicates that the UPFI has consistently attempted to form a closer relationship with civil society in the global NCD space. A number of global NGOs have received funding from the UPFI (CS-1, CS-2, CS-9): the World Heart Federation, for instance, has historically received funds from Unilever ${ }^{74}$ and the International Diabetes Federation from Nestlé. ${ }^{86}$ Civil society interviewees reported that UPFI offers of financial support, as well as invites to attend and present at industry-organised events or join industry panels, were common (ex-IO-1, CS-1). One senior advocate recalled:

I was almost stalked by [soda company] and [soda company]. They would have given me as much money as I wanted. You know, I would go to meetings and then suddenly I would find that they were there, and I was invited to go speak to their board. (CS-1)

They attributed such efforts to the UPFI's desire to foster credibility and dampen civil society criticism (CS-1, CS-2).

Establishing collaborations with NGOs may also facilitate access to global policymaking. This was illustrated by PepsiCo and Coca-Cola's active participation in the NCD Roundtable, which was convened to discuss policy recommendations for WHO's work on NCDs and the 2011 HLM by the Global Health Council, a US-based membership 
organisation in official relations with $\mathrm{WHO}^{88}$ On becoming members of the Council, PepsiCo and CocaCola were able to feed into these policy recommendations via the Roundtable, and qualified to participate in the World Health Assembly and other high-level events as part of its delegation. ${ }^{89}$ Harnessing another privilege granted to the Global Health Council with official relations status, PepsiCo co-sponsored a multi-stakeholder dialogue at the UN in the lead-up to the HLM, affording the company and its invited representatives access to decision-makers. ${ }^{89}$

Seven interviewees described the relationship between civil society and industry as significantly closer in the nutrition space than the more focused NCD space (IO-3, ex-IO-2, CS-3, CS-5, CS-6, CS-7, CS-8, CS-9). For instance, malnutrition-focused organisations such as the Global Alliance for Improved Nutrition foundation and the Scaling up Nutrition Movement have commonly entered or promoted partnerships with major UPFI actors. Scaling up Nutrition also hosts a Business Network, co-convened by the Global Alliance for Improved Nutrition and the UN World Food Programme, which includes PepsiCo, Mars, and Kellogg's. ${ }^{90}$

\section{Hiring former WHO staff}

Food corporations have hired former WHO officials (CS-1). For example, Derek Yach, a former Executive Director for NCDs, was recruited by PepsiCo as Senior Vice President in 2007. While employed at WHO under DG Brundtland, Yach played a role in organising dialogues with industry; in his role at PepsiCo, he later sat on the other side of the table. ${ }^{86891}$ PepsiCo also recruited Yach's previous superior, Gro Harlem Brundtland, to its Blue Ribbon Advisory Board in 2007. ${ }^{92}$ Similarly, Janet Voûte, previously head of the World Heart Federation, led the development of WHO's NCD Network immediately before joining Nestlé as Global Head of Public Affairs. ${ }^{93}$ This technique can facilitate access to public health communities through former officials' networks and credibility (CS-1).

\section{Involvement and influence in policymaking}

All types of data we analysed indicated that UPFI actors are able to access WHO policy processes through formal routes, a technique which is facilitated by coalition management. There was also evidence of less a prominent technique: intimidating policymakers.

\section{Participating in WHO processes}

UPFI actors regularly engaged with WHO on NCD policy through consultations, hearings and meetings (IO- 1 , IO-2, IO-3, IO-4, ex-IO-1, ex-IO-2, CS-3, CS-4, CS-5, CS-6, CS-7, CS-8, CS-9), ${ }^{38} 7475$ where they consistently opposed statutory regulation favour of voluntary approaches. ${ }^{45} 94$ In line with the WHO's approach to industry engagement, this primarily occurs through business associations. ${ }^{34}$ Regular dialogues between the WHO DG, officials and the UPFI, first set up in 2003 by DG Brundtland, ${ }^{91} 95$ occur primarily through IFBA, with corporations attending as members (IO-1, IO-2, IO-4, ex-IO-1, CS-6) ${ }^{96}$ At the civil society hearing preceding the third HLM, the speaker panel included IFBA's Secretary-General. ${ }^{97}$

The ability of individual corporations to engage as members of associations is notable. Nestlé and Unilever, for instance, spoke as IFBA members at a meeting organised by the WHO Global Coordination Mechanism on NCDs. ${ }^{98}$ Although business associations are eligible to obtain WHO official relations status, no key UPFI groups currently hold it, after International Special Dietary Industries were stripped of it in $2013^{100}$ and ILSI in $2015,{ }^{79} 101102$ following the revelation that one of its member companies was owned by a tobacco conglomerate. Although it seems that IFBA previously attempted to gain official relations status (IO-3) it has not succeeded to date. ${ }^{8688}$

\section{Intimidating policymakers}

Three interviewees discussed 2 separate cases, where UPFI representatives exhibited verbally intimidating behaviour towards IO staff (IO-4, ex-IO-1, ex-IO-2). These interviews are the only evidence we identified of such conduct.

\section{Information management}

Our analysis suggests that the UPFI engaged in information management, simultaneously producing and disseminating information supporting its preferred policy positions and challenging unfavourable information perceived as threatening.

\section{Sponsoring or disseminating favourable information}

UPFI actors have funded and disseminated research to favourably influence policy debates (CS-1, CS-2, CS-8, ex-IO-1) ${ }^{79}{ }^{80}$ Industry-linked SPIs in particular play an important role in funding and disseminating favourable research, reports or policy documents. Scientists funded by ILSI, for instance, have supported and enabled the dissemination of industry-favourable narratives. ${ }^{79} 80$ The World Sugar Research Organization commissioned a report warning that the 2004 Global Strategy recommendation on sugar reduction would have severe economic impacts on low-income and middle-income countries, ${ }^{56}$ which was sent to the Food and Agriculture Organization's DG and national policymakers. ${ }^{59}$ Similarly, one interviewee noted:

[Business associations] prepare for the [WHO] governing bodies meetings. They design the lobby strategy in terms of policy recommendations they have, and they fund all these think tanks, they prepare policy papers that are leafleted to governments, to missions. And in this, they are much smarter than civil society organisations, I must say. (CS-8)

Furthermore, IFBA affiliates have published in reputable public health journals, advocating an important role for the UPFI in global health. ${ }^{91} 103104$ More generally, consultations and hearings provide a platform for the UPFI to advance favourable evidence. ${ }^{98} 99$ 
Challenging or undermining unfavourable information

Simultaneously, UPFI actors have attempted to delegitimise WHO guidance, primarily by denying its evidence base (IO-1, CS-5). ${ }^{56} 58-60747980$ For example, the sugar industry campaign against the 2004 Global Strategy was rooted in challenges to the science underpinning it. ${ }^{56} 5972$ Commercial actors may also attempt to suppress unfavourable voices: a study of internal ILSI documents suggest that the organisation 'can be deployed to marginalise unfavourable positions, which supports the argument that it is a front for industry when positions need to be quashed. ${ }^{80}$ This technique is connected to civil society co-optation which may similarly curtail criticism.

\section{UPFI reputation management}

The UPFI has used corporate social responsibility (CSR) activities, including participation in global public-private partnerships, to maintain and enhance legitimacy in the global health policy space (IO-1, IO-2, CS-6, CS-7) ${ }^{89} 105-107$ Portrayals of corporations as socially responsible are omnipresent in UPFI reports and often invoke the Sustainable Development Goals (SDGs). ${ }^{108-110}$ Alongside partnerships with NGOs, CSR has included contributions to and collaboration with IOs such as the UN Development Programme around access to clean water, and UN Women, supporting female entrepreneurs. ${ }^{107}$ Another example is Project Last Mile, which uses Coca-Cola's supply chain expertise to deliver medicines alongside partners such as the Global Fund and the Bill and Melinda Gates Foundation. ${ }^{111}$ One interviewee noted:

\section{[...] I can totally understand what's in it for the Global Fund, having a partnership with Coke. Because Coke, as far as I can see, have the best supply chain in the world. They can get to places that have civil wars. You can't get rice, but you can get a Coke. [...] I don't think they've really reflected on how the SDGs are supposed to be seen as a whole, so you shouldn't really be partnering with organisations that are detrimental across a whole swathe of other SDGs. (CS-6)}

Despite potentially positive elements, such initiatives may detract from a company's negative health impacts and serve to 'blue-wash'its image through association with IOs. ${ }^{107}$ Moreover, existing partnerships, voluntary initiatives, and commitments around NCDs are consistently promoted as alternatives to statutory regulation. ${ }^{45}$ Two interviewees argued that in its commitments to WHO, the UPFI has predominantly embraced 'low-hanging fruit' which poses a lesser threat to profitability, such as trans-fat reduction, ${ }^{112}$ to appear responsible while delaying regulatory action in areas such as sugar reduction and advertising (CS-5, CS-7).

\section{Perceived differences with tobacco industry behaviour}

Interviewees widely described the UPFI as an accepted actor in NCD policy, particularly compared with the tobacco industry. They attributed this primarily to perceived differences in product 'harmfulness' and the relative heterogeneity of the food industry (IO-1, ex-IO-2, CS-1, CS-7). Overall, the political behaviour of the UPFI was perceived as less antagonistic than that of the tobacco industry, with two potential explanations given: the comparatively lower degree of regulatory pressure in the dietary NCD policy space and a degree of pre-emption based on the tobacco company misconduct which, when publicised, contributed to the denormalisation of their industry (CS-6, CS-7).

\section{DISCUSSION}

This study addresses a significant gap in the understanding of UPFI political activity by examining its instrumental strategies in global-level NCD policy. In summary, our analysis suggests that the UPFI uses three overarching strategies which interlink and reinforce each other: coalition management, involvement and influence in policymaking, and information management (figure 1). UPFI actors established and used favourable coalitions-with allied Member States, SPIs, and between businessesto promote their preferred policy positions, while they sought to co-opt civil society coalitions and hired former WHO staff. Pursuant to WHO guidelines, participation in consultations and meetings primarily takes place through the aforementioned groups. Moreover, the UPFI managed information strategically, funding and promoting evidence and other information favourable to their policy preferences, while challenging unfavourable information. Lastly, UPFI actors' CSR activities and much-publicised partnerships were attributed to attempts to create a reputation as responsible, legitimate actors.

The first key limitation of this work is that we had restricted access to interviewees, notably those from IOs. This is likely a consequence of the unavoidable limitations imposed by the COVID-19 pandemic as well as the professional risk involved in discussing politically sensitive topics in the absence of freedom of information provisions within the UN system. Second, the documents analysed in this study were drawn from a limited pool of internal industry files. As such, our data do not provide a comprehensive picture of UPFI activities. Third, over half of the identified academic articles were commentaries, news pieces or editorials by individuals involved in WHO processes, rather than original research, which highlights the need for more empirical work in this area. Moreover, WHO is not the only IO involved in dietary NCD policy, thus further research addressing the wider UN system is necessary to better understand the UPFI's role.

We sought to overcome these limitations in a number of ways. Notably, we used a conceptual model based on high evidential standards from the tobacco literature to structure our enquiry. The PDM has been successfully used to analyse political activities of the UPFI and other industries, ${ }^{13} 14{ }^{42-44}$ showing similar tactics at the national level and thus providing a priori evidence to suggest comparable tactics at the global level. Nonetheless, there remains a need for a joint-up framework based on rigorous analysis of evidence from multiple unhealthy commodity industries, which would offer a 


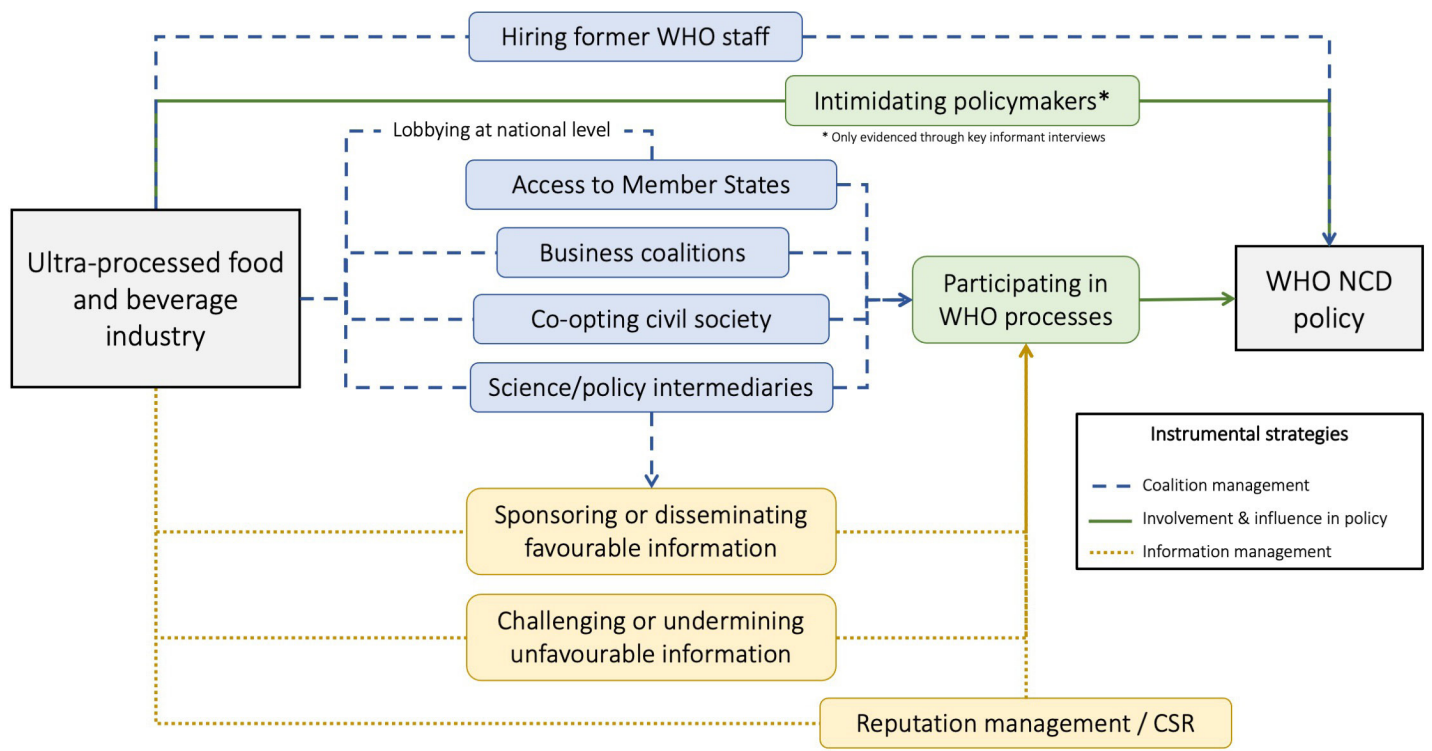

Figure 1 Overview of strategies and techniques identified. CSR, corporate social responsibility; NCD, non-communicable disease.

more appropriate basis for cross-industry research. We also triangulated multiple data sources to overcome weaknesses of each. ${ }^{49}$ While we did not approach UPFI representatives for this study, two studies have analysed their public views on NCD policy at the WHO and the industry's role within it in depth, ${ }^{45}{ }^{113}$ finding that UPFI groups have consistently opposed statutory regulation in favour of self-regulatory approaches, and promoted a strong role for industry in policymaking while emphasising the limits of WHO's mandate and fostering a narrow understanding of conflict of interest. ${ }^{45113}$ Together with the current findings that the UPFI engages in a broad range of techniques to achieve these policy preferences, this renders questionable whether they can meaningfully contribute to policy development as they claim.

The UPFI remains able to exert significant structural, instrumental and discursive power in global health and nutrition governance. ${ }^{114}$ Our analysis accentuates a power imbalance which compromises the ability of global health governance to deliver in the public interest. The food industry is enormously heterogenous, but only a narrow subset of actors has the resources and capacity to engage with IOs. This imbalance means that it is easier for UPFI multinationals to have their voices heard than for parts of the food industry whose practices may be less damaging or even beneficial to health and who may therefore have a role to play, and for civil society or people living with NCDs who are more likely to represent the public interest. Although smaller actors within the food industry are likely to lack the resources for sustainable IO engagement, movements such as La Via Campesina, which has a long history of representing small-scale food producers at the UN Food and Agriculture Organization, ${ }^{115}$ provide a potential route for engagement. Speaking to a further power imbalance, our research highlights how high-income countries hosting major food companies can stymie efforts, primarily of low-income and middle-income countries, to effectively address NCDs. Addressing rather than reinforcing such power imbalances should be central to considerations on engagement and partnerships, at national and global level.

The food industry enjoys a high degree of acceptability in global health policy circles. The heterogeneity of this unhelpfully broad category seems to play a key role in legitimising those companies whose practices are most detrimental to health, and it closely links to UPFI multinationals' own framing of themselves as 'part of the solution' and attempts to mitigate conflict of interest as unfair vilification. ${ }^{13} 45113116117$ However, their political behaviour is strikingly similar to that of the tobacco industry. In fact, our study is one among a growing body of literature which documents parallels between a range of unhealthy commodity industries. ${ }^{118-120}$ Like at national level, ${ }^{121}$ we identify similarities in the political behaviour of the UPFI and tobacco industries at the global level. Analyses of internal documents show the tobacco industry's aggressive campaign to delay and weaken the WHO FCTC, including lobbying through allied Member States and SPIs to oppose the regulation of their products, and recruiting ex-WHO staff, ${ }^{46-48} 122$ all of which we document the UPFI using here.

Overall, this coherence in behaviour demands greater coherence in governance approaches to unhealthy commodity industries. ${ }^{33123124}$ This is likely to remain contentious in light of the public health community's ambiguity on interactions with the food industry compared with other unhealthy commodity industries, ${ }^{125}$ but others have suggested that the FCTC, specifically the way in which it deals with the conflict of interest between the tobacco industry and public health, provides a potential pathway for action on healthier diets. ${ }^{33}$ Although 
arguably neither perfect nor easy to implement at country level, FCTC Article 5.3, which aims to protect public health policymaking from tobacco industry interference, has had some success in reinforcing tobacco control. ${ }^{126-128}$ Our findings suggest that comprehensive, effective safeguards against undue influence and conflicts of interest are paramount for WHO to fulfil its role as a global leader in tackling NCDs. This is especially pertinent in light of the new WHO Foundation which renders it possible to circumvent WHO rules on corporate donations and thus poses a clear threat to the agency's independence, ${ }^{124}$ as illustrated by a widely publicised donation from Nestlé in April 2021. ${ }^{129}$

The need for comprehensive safeguards against commercial interference inevitably extends to national settings: UPFI attempts to influence NCD policy through Member State governments have the potential to impede urgently needed action to address dietary NCDs globally. While we highlight such activities at the global level, there is evidence that similar mechanisms are at work between countries: some of our interviewees reported joint lobbying by the Italian embassy and a food company in Latin American countries, and after Chile introduced ground-breaking marketing restrictions and labelling rules, a public health official reported being accused of 'food terrorism' by a Ferrero executive and the Italian ambassador. ${ }^{130}$

We also observe tensions between attempts to address NCDs on one hand and undernutrition and micronutrient deficiencies on the other hand, the latter often affording a substantial role to the UPFI. ${ }^{131}$ With the double burden of malnutrition and NCDs prevalent within countries, communities and even individuals, ${ }^{132}$ undernutrition and overnutrition cannot be tackled separately, particularly considering that the distribution of food products by multinational corporations, a key driver of unhealthy diets, is touted as a solution to the latter by some. This underlines the need to adopt a focus on double-duty actions which tackle the common drivers of malnutrition. ${ }^{133}$

\section{CONCLUSIONS}

This work provides a means of understanding and thus addressing how the UPFI attempts to prevent or weaken regulation at global level. COVID-19 has reminded us that a strong WHO is essential for global public health. What happens in global-level policymaking, and what does not, is important. Strong recommendations on NCDs from the UN and its agencies can provide Member States with a mandate to act, while their absence offers the UPFI a means to oppose regulation. Reconsidering multistakeholder approaches which have allowed commercial interests a seat at the public health policy table may be key to rebuilding a healthier world post-COVID-19. ${ }^{134}$ By highlighting UPFI attempts to interfere with WHO's efforts to curb NCDs, we provide a foundation for further steps to protect the agency's work against a set of problems that presents an even greater long-term challenge to global health than the current pandemic. The implementation of stronger conflict of interest measures would be an important first step in addressing power imbalances between Member States, the UPFI, and civil society to more effectively address dietary NCDs.

Twitter Kathrin Lauber @kathrin_lauber and Harry Rutter @harryrutter

Acknowledgements We would like to thank all participants for their time and trust, and Dr Britta Katharina Matthes for her thoughtful comments on a draft of this manuscript.

Contributors $K L$ developed the study methodology with guidance from $A B G$ and HR. KL collected the data and conducted the analysis and wrote the draft with key input from ABG. HR and ABG provided edits and feedback. All authors revised and approved the manuscript.

Funding $\mathrm{KL}$ is funded by the Roger and Sue Whorrod PhD Studentship. ABG and HR received funding from SPECTRUM for this work, a UK Prevention Research Partnership (UKPRP, https://ukprp.org) Consortium. UKPRP is an initiative funded by the UK Research and Innovation Councils, the Department of Health and Social Care and the UK devolved administrations and leading health research charities.

Disclaimer The funders had no role in study design, data collection and analysis, decision to publish or preparation of the manuscript.

Competing interests $A B G$ receives funding from Bloomberg Philanthropies for the Stopping Tobacco Organizations and Products project. KL is part of the same research group which receives funding from Bloomberg Philanthropies.

Patient consent for publication Not required.

Ethics approval The University of Bath's Research Ethics Approval Committee for Health approved this research (EP 18/19068).

Provenance and peer review Not commissioned; externally peer reviewed.

Data availability statement All documentary data and literature relevant to the study are publicly available. Interview data will not be shared to maintain confidentiality.

Supplemental material This content has been supplied by the author(s). It has not been vetted by BMJ Publishing Group Limited (BMJ) and may not have been peer-reviewed. Any opinions or recommendations discussed are solely those of the author(s) and are not endorsed by BMJ. BMJ disclaims all liability and responsibility arising from any reliance placed on the content. Where the content includes any translated material, BMJ does not warrant the accuracy and reliability of the translations (including but not limited to local regulations, clinical guidelines, terminology, drug names and drug dosages), and is not responsible for any error and/or omissions arising from translation and adaptation or otherwise.

Open access This is an open access article distributed in accordance with the Creative Commons Attribution 4.0 Unported (CC BY 4.0) license, which permits others to copy, redistribute, remix, transform and build upon this work for any purpose, provided the original work is properly cited, a link to the licence is given, and indication of whether changes were made. See: https://creativecommons.org/ licenses/by/4.0/.

\section{ORCID iDs}

Kathrin Lauber http://orcid.org/0000-0003-0073-3004

Harry Rutter http://orcid.org/0000-0002-9322-0656

\section{REFERENCES}

1 World Health Organization. Global action plan for the prevention and control of NCDs 2013-2020. Geneva: World Health Organization; 2013.

2 Murray CJL, Aravkin AY, Zheng P, et al. Global burden of 87 risk factors in 204 countries and territories, 1990-2019: a systematic analysis for the global burden of disease study 2019. Lancet 2020;396:1223-49.

3 Swinburn BA, Kraak VI, Allender S, et al. The global Syndemic of obesity, undernutrition, and climate change: the Lancet Commission report. Lancet 2019;393:791-846.

4 Mialon M, Swinburn B, Allender S, et al. 'Maximising shareholder value': a detailed insight into the corporate political activity of the Australian food industry. Aust N Z J Public Health 2017;41:165-71. 
5 Vandenbrink D, Pauzé E, Potvin Kent M. Strategies used by the Canadian food and beverage industry to influence food and nutrition policies. Int J Behav Nutr Phys Act 2020;17:3.

6 Tselengidis A, Östergren P-O. Lobbying against sugar taxation in the European Union: analysing the lobbying arguments and tactics of stakeholders in the food and drink industries. Scand J Public Health 2019;47:565-75.

7 Greenhalgh S. Soda industry influence on obesity science and policy in China. J Public Health Policy 2019;40:5-16.

8 Hillman AJ, Keim GD, Schuler D. Corporate political activity: a review and research agenda. J Manage 2004;30:837-57.

9 Savell E, Gilmore AB, Fooks G. How does the tobacco industry attempt to influence marketing regulations? A systematic review. PLoS One 2014;9:e87389.

10 Ulucanlar S, Fooks GJ, Gilmore AB. The policy Dystopia model: an interpretive analysis of tobacco industry political activity. PLOS Med 2016;13:e1002125.

11 Ojeda E, Torres C, Carriedo Ángela, et al. The influence of the sugar-sweetened beverage industry on public policies in Mexico. Int J Public Health 2020:65:1037-44.

12 Mialon M, Gaitan Charry DA, Cediel G, et al. "The architecture of the state was transformed in favour of the interests of companies": corporate political activity of the food industry in Colombia. Global Health 2020;16:97.

13 Mialon M, Crosbie E, Sacks G. Mapping of food industry strategies to influence public health policy, research and practice in South Africa. Int J Public Health 2020;65:1027-36.

14 Abdool Karim S, Kruger P, Hofman K. Industry strategies in the parliamentary process of adopting a sugar-sweetened beverage Tax in South Africa: a systematic mapping. Global Health 2020;16:116.

15 Jaichuen N, Phulkerd S, Certthkrikul N, et al. Corporate political activity of major food companies in Thailand: an assessment and policy recommendations. Global Health 2018;14:115.

16 Hunt D. How food companies use social media to influence policy debates: a framework of Australian ultra-processed food industry Twitter data. Public Health Nutr 2020:1-12.

17 Maani Hessari N, Ruskin G, McKEE M, et al. Public meets private: conversations between Coca-Cola and the CDC. Milbank Q 2019;97:74-90.

18 Mulligan C, Jawad A, Kent MP, et al. Stakeholder interactions with the federal government related to bill S-228 and marketing to kids in Canada: a quantitative descriptive study. CMAJ Open 2021;9:E280-7.

19 Bloom DE, Cafiero ET, Jané-Llopis E, Abrahams-Gessel S, Bloom LR, Fathima S, Feigl AB, Gaziano T, Mowafi M, Pandya A, Prettner K, Rosenberg L, Seligman B, Stein A, Weinstein C. The global economic burden of non-communicable diseases. Geneva: World Economic Forum; 2011.

20 United Nations General Assembly. Political Declaration of the high-level meeting of the general assembly on the prevention and control of non-communicable diseases. New York: United Nations; 2011.

21 United Nations General Assembly. Outcome document of the highlevel meeting of the general assembly on the comprehensive review and assessment of the progress achieved in the prevention and control of non-communicable diseases. Geneva: United Nations; 2014.

22 United Nations General Assembly. Political declaration of the third high-level meeting of the general assembly on the prevention and control of non-communicable diseases. New York: United Nations; 2018.

23 World Health Organization. WHO framework convention on tobacco control. Geneva: World Health Organization; 2003.

24 Kickbusch I. COVID-19 is smoke and Mirrors-What matters is international law. Think Global Health 2020 https://www. thinkglobalhealth.org/article/covid-19-smoke-and-mirrors-whatmatters-international-law

25 Magnusson R. Non-Communicable Diseases and Global Health Politics. In: Mclnnes C, Lee K, Youde J, eds. The Oxford Handbook of global health politics. Oxford: Oxford University Press, 2019.

26 Nishtar S, Niinistö S, Sirisena M, et al. Time to deliver: report of the WHO independent high-level Commission on NCDs. Lancet 2018;392:245-52.

27 Lieberman A. UN meeting on NCDs falls short on hard commitments, civil society say, 2018. Devex. Available: https:// www.devex.com/news/un-meeting-on-ncds-falls-short-on-hardcommitments-civil-society-say-93547 [Accessed 12 May 2021].

28 NCDAlliance. ENOUGH: over 300 organisations and experts calls on world leaders to seize the 'do or die' moment of the third UN High-Level Meeting to address NCDs, 2018. Available: https://ncdalliance.org/news-events/news/enough-nearly-300organisations-and-experts-calls-on-world-leaders-to-seize-the-\% E2\%80\%98do-or-die\%E2\%80\%99-moment-of-the-third-un-highlevel-meeting-to-address-ncds [Accessed 12 May 2021].

29 Keaten J, Cheng M. US blocks UN health panel from backing taxes on sugar drinks. Associated press news $2018 \mathrm{https}: / /$ www.citizen. org/news/us-blocks-un-health-panel-from-backing-taxes-on-sugardrinks/

30 Hanefeld J, Hawkins B. NCDs - it's time to embrace the evidence, not industry. BMJ Blogs 2018.

31 Horton R. Offline: NCDs, WHO, and the neoliberal utopia. Lancet 2018:391:2402-02.

32 Askew K. UN commitment to tackling NCDs: 'Landmark step' or 'lacking ambition'? Food Navigator 2018 https://www. foodnavigator.com/Article/2018/10/02/UN-commitment-totackling-NCDs-Landmark-step-or-lacking-ambition

33 Collin J. Tobacco control, global health policy and development: towards policy coherence in global governance. Tob Control 2012;21:274-80.

34 World Health Organization. Framework of engagement with nonState actors. Geneva: World Health Organization; 2016.

35 Khayatzadeh-Mahani A, Ruckert A, Labonté R. Could the WHO's Framework on Engagement with Non-State Actors (FENSA) be a threat to tackling childhood obesity? Glob Public Health 2018;13:1337-40.

36 World Health Organization. Non-State actors in official relations with WHO, 2021. Available: https://www.who.int/about/ partnerships/non-state-actors/non-state-actors-in-official-relationswith-who [Accessed 22 Jan 2021].

37 Buse K, Hawkes S. Sitting on the FENSA: WHO engagement with industry. Lancet 2016;388:446-7.

38 Casswell S. Addressing NCDs: Penetration of the Producers of Hazardous Products into Global Health Environment Requires a Strong Response Comment on "Addressing NCDs: Challenges From Industry Market Promotion and Interferences". Int $J$ Health Policy Manag 2019;8:607-9.

39 Bero L. Implications of the tobacco industry documents for public health and policy. Annu Rev Public Health 2003;24:267-88.

40 Tobacco industry documents Archive, 2021. University of California San Francisco. Available: https://www.industrydocuments.ucsf. edu/tobacco/ [Accessed 19 Jan 2021].

41 Food industry documents Archive, 2021. University of California San Francisco. Available: https://www.industrydocuments.ucsf. edu/food/ [Accessed 19 Jan 2021].

42 Mialon M, Julia C, Hercberg S. The policy dystopia model adapted to the food industry: the example of the Nutri-Score SAGA in France. World Nutrition 2018:9:109-20.

43 Mialon M, Gomes FdaS. Public health and the ultra-processed food and drink products industry: corporate political activity of major transnationals in Latin America and the Caribbean. Public Health Nutr 2019;22:1898-908.

44 Paixão MM, Mialon M. Help or hindrance? The alcohol industry and alcohol control in Portugal. Int J Environ Res Public Health 2019:16:4554.

45 Lauber K, Ralston R, Mialon M, et al. Non-Communicable disease governance in the era of the sustainable development goals: a qualitative analysis of food industry framing in who consultations. Global Health 2020;16:76.

46 Weishaar H, Collin J, Smith K, et al. Global health governance and the commercial sector: a documentary analysis of tobacco company strategies to influence the who framework convention on tobacco control. PLoS Med 2012;9:e1001249.

47 World Health Organization. Tobacco company strategies to undermine tobacco control activities at the world Health organization: report of the Committee of experts on tobacco industry documents. Geneva: World Health Organization; 2000.

48 Gonzalez M, Green LW, Glantz SA. Through tobacco industry eyes: civil Society and the FCTC process from Philip Morris and British American tobacco's perspectives. Tob Control 2012;21:e1.

49 Lee K, Hawkins B. Researching corporations and global health governance: an interdisciplinary guide. London: Rowman \& Littlefield International, 2016.

50 Baker P. Chapter 26 - Doing Health Policy Research: How to Interview Policy Elites. In: Banwell C, Ulijaszek S, Dixon J, eds. When culture impacts health. San Diego: Academic Press, 2013: 309-17.

51 Aberbach JD, Rockman BA. Conducting and coding elite interviews. PS: Political Science \& Politics 2002;35:673-6.

52 Forster $\mathrm{N}$. The analysis of company documentation. In: Cassell C, Symon G, eds. Qualitative methods in organizational research. Newcastle: Sage, 1994. 
53 Braun V, Clarke V. Successful qualitative research: a practical guide for beginners. London: Sage, 2013.

54 QSR InternationaINVivo qualitative data analysis software. 12. 2018.

55 Cherry K. International Government Relations \& Public Affairs Activities Week of March 16, 2015 DC Leaks Coca Cola Emails: DC Leaks, 2015. Available: https://www.industrydocuments.ucsf.edu/ docs/fmdl0226

56 Norum KR. World Health Organization's Global Strategy on diet, physical activity and health: the process behind the scenes. Scandinavian Journal of Nutrition 2005;49:83-8.

57 Goltzman M. FW: UPDATED INFORM: World Health Assembly May 26 DC Leaks Coca Cola Emails: DC Leaks, 2015. Available: https://www.industrydocuments.ucsf.edu/docs/kjdl0226

58 Boseley S. Political context of the World Health Organization: sugar industry threatens to scupper the WHO. Int $J$ Health Serv 2003;33:831-3.

59 Waxman A. The WHO global strategy on diet, physical activity and health: the controversy on sugar. Development 2004;47:75-82.

60 Management by objectives Western sugar cooperative ADM litigation: center for science in the public interest, 2003. Available: https://www.industrydocuments.ucsf.edu/docs/gtpj0226

61 Goltzman M. FW: INFORM: International Food \& Beverage Alliance 2014 Progress Report DC Leaks Coca Cola Emails: DC Leaks, 2015. Available: https://www.industrydocuments.ucsf.edu/docs/ hzcl0226

62 The Permanent Mission of Italy to the International Organizations in Geneva. Informative meeting on the annual "Foreign Policy and Global Health" United Nations General Assembly Resolution: Statement by the Permanent Representative of Italy to the International Organizations in Geneva, Ambassador Gian Lorenzo Cornado, 2018. Available: https://web.archive.org/web/ 20201106193011/https://italiarappginevra.esteri.it/rappginevra/ resource/doc/2018/11/statement_ambassador_cornado.pdf [Accessed 6 Nov 2020].

63 The Permanent Mission of Italy to the International Organizations in Geneva. United Nations General Assembly Resolution on nutrition - Remarks by the Italian Minister of Foreign Affairs, Enzo Moavero Milanesi, 2018. Available: https://web.archive.org/web/ 20200424085443/https://italiarappginevra.esteri.it/rappginevra/ en/ambasciata/news/dall-ambasciata/2018/12/risoluzione-dellassemblea-generale.html [Accessed 24 Apr 2020].

64 The Permanent Mission of Italy to the International Organizations in Geneva. Press release with reference to the demarches made with the Italian government by Dr. Francesco Branca, director of the department of nutrition for health and development of WHO and by Prof. Anna Lartey, director for nutrition of FAO, both members of the EAT-Lancet commission on food, planet and health, 2019. Available: https://web.archive.org/web/ 20200514184918/https://italiarappginevra.esteri.it/rappginevra/ en/ambasciata/news/dall-ambasciata/2019/11/comunicato 0.htm [Accessed 14 May 2020].

65 World Health Organization. Guideline: sugars intake for adults and children. Geneva: World Health Organization; 2015.

66 Dentico N. Forza Zucchero! Salute Internazionale 2015 https:// www.saluteinternazionale.info/2015/02/forza-zucchero/

67 World Health Organization. Proposal for a supplementary agenda item. Geneva: World Health Organization; 2015.

68 World Health Organization. Executive board 136th session and special session on Ebola. List of members and other participants: members, alternates and advisers. Geneva: World Health Organization; 2015.

69 inGenere. Voucher universali per la cura. Un dibattito a Roma Rome, 2014. Available: https://web.archive.org/web/ 20200522104336/https://www.ingenere.it/agenda/voucheruniversali-la-cura-un-dibattito-roma [Accessed 22 May 2020].

70 Torjesen I. WHO pulls support from initiative promoting global move to plant based foods. BMJ 2019;365:11700.

71 Briscoe A. Sugar association letter to WHO, 2003. Available: https://archive.org/details/458188-sugar-association-letter-to-whoapril-2003/page/n1/mode/2up [Accessed 08 Nov 2020].

72 Dyer O. US government rejects WHO's attempts to improve diet. BMJ 2004;328:185.

73 Steiger W. HHS letter to WHO director General, 2004. Available: https://archive.org/details/486456-hhs-letter-to-who-directorgeneral-january-2004/mode/2up [Accessed 08 Nov 2020].

74 Cohen D. Will industry influence derail UN Summit? BMJ 2011;343:d5328

75 Stuckler D, Basu S, McKee M. Commentary: UN high level meeting on non-communicable diseases: an opportunity for whom? BMJ 2011;343:d5336.
76 U.S. Chamber of Commerce. U.S. chamber statement on the world Health organization, 2020. Available: https://web.archive.org/web/ 20210129184224/https://www.uschamber.com/press-release/uschamber-statement-the-world-health-organization [Accessed 29 Jan 2021].

77 US Council for International Business. USCIB mission to Geneva targets UN agencies, 2018. Available: https://web.archive.org/web/ 20200810180334/https://www.uscib.org/uscib-mission-to-genevatargets-un-agencies/ [Accessed 10 Aug 2020].

78 Malaspina A. Re: Daily European Ness Flash - 25.06.15. USRTK Food Industry Collection. USRTK Food Industry Collection: US Right to Know, 2015. Available: https://www.industrydocuments. ucsf.edu/docs/kpcy0227

79 Steele S, Ruskin G, Sarcevic L, et al. Are industry-funded charities promoting "advocacy-led studies" or "evidence-based science"?: a case study of the International Life Sciences Institute. Global Health 2019;15:36.

80 Steele S, Ruskin G, Stuckler D. Pushing partnerships: corporate influence on research and policy via the International life sciences Institute. Public Health Nutr 2020;23:2032-40.

81 International Life Sciences Institute. Form 990 return of organization exempt from income tax 2012, 2013. ProPublica. Available: https://projects.propublica.org/nonprofits/display_990/ 521131788/2013_12_EO\%2F52-1131788_990_201212 [Accessed 30 Aug 2020]

82 International Life Sciences Institute. Form 990 return of organization exempt from income tax 2013, 2014. ProPublica. Available: https://projects.propublica.org/nonprofits/organizations/ 521131788/201423119349300642/full [Accessed 30 Aug 2020].

83 International Life Sciences Institute. Form 990 return of organization exempt from income tax 2015, 2017. ProPublica. Available: https://projects.propublica.org/nonprofits/display_990/ 521131788/2017 02_EO\%2F52-1131788 990201512 [Accessed 30 Aug 2020]

84 Stuckler D, Basu S, McKee M. Global health philanthropy and institutional relationships: how should conflicts of interest be addressed? PLoS Med 2011;8:e1001020.

85 KPMG. Annual Tax return, form 990-PF: return of private Foundation. 2020. Washington DC: Bill and Melinda Gates Foundation, 2019.

86 Wilson D, Kerlin A. Special Report - Food, beverage industry pays for seat at health-policy table. Reuters 2012 https://www.reuters. com/article/uk-obesity-who-industry/special-report-food-beverageindustry-pays-for-seat-at-health-policy-table-idUKBRE89I0KC201 21019

87 Nestlé. Nestlé in society, 2012. Available: https://web.archive.org/ web/20201026215400/https://www.nestle.com/sites/default/files/ asset-library/documents/library/documents/corporate_social responsibility/nestle-csv-full-report-2012-en.pdf [Accessed 26 Oct 2020].

88 World Health Organization. List of entities in official relations with WHO, 2021. Available: https://www.who.int/publications/m/item/ non-state-actors-in-official-relations-with-who [Accessed 22 Jan 2021].

89 Moscetti CW, Taylor AL. Take me to your liter: politics, power and public-private partnerships with the sugar-sweetened beverage industry in the post-2015 development agenda. Wash Int'/ LJ 2015;24:635.

90 Scaling up Nutrition Business Network. Global members, 2020. Available: https://web.archive.org/save/https:// sunbusinessnetwork.org/network/global-members/ [Accessed 16 Aug 2020].

91 Yach D, Khan M, Bradley D, et al. The role and challenges of the food industry in addressing chronic disease. Global Health 2010;6:10.

92 PepsiCo. 2007 annual report. Harrison, New York: PepsiCo; 2008.

93 World Public Health Nutrition Association. WHO, transnational industry: the door revolves again, 2010. Available: http://archive. wphna.org/wp-content/uploads/2013/08/2010_November_Janet Voute joins_Nestle.pdf [Accessed 12 May 2021].

94 Whitaker K, Webb D, Linou N. Commercial influence in control of non-communicable diseases. BMJ 2018;360:k110.

95 World Health Organization. WHO continues dialogue with food and beverage industry executives on diet and chronic diseases, 2003. Available: https://www.who.int/mediacentre/news/notes/2003/ np21/en/ [Accessed 12 May 2021].

96 World Health Organization. Roundtable on noncommunicable diseases - strengthening the role and contribution of the food and non-alcoholic beverage industry to respond to the 2011 Political Declaration of the High-level Meeting of the General Assembly on the Prevention and Control of NCDs. Geneva: 
World Health Organization; 2018. https://www.who.int/ncds/ governance/food-and-non-alcoholic-beverages-dialogue26062018.pdf

97 Stuckler D, Reeves A, Loopstra R, et al. Textual analysis of sugar industry influence on the world Health organization's 2015 sugars intake guideline. Bull World Health Organ 2016;94:566-73.

98 Hanson CB. We deliver: creating shared value, we seek: effective engagement. Nestlé presentation to the WHO global coordination mechanism on the prevention and control of NCDs. making progress on the public health agenda, 2015. World Health organization. Available: https://www.who.int/global-coordinationmechanism/Session-2-Chavanne-Hanson-GCM-NestleFinal2.pdf [Accessed 12 May 2021].

99 Heughan A. Engagement with the private sector. Unilever presentation to the WHO global coordination mechanism on the prevention and control of NCDs, 2015. World Health Organization. Available: https://www.who.int/global-coordination-mechanism/ session2-Anne-Heughan-Nutrition-Health-WHOJune2015-Unilever. pdf [Accessed 12 May 2021].

100 Rundall P. Update 46 - page 14: WHO and commercial influence: baby milk action, 2013. Available: http://www.babymilkaction.org/ update46page14 [Accessed 14 Aug 2020].

101 Hentges E. ILSI's Official Relations with the World Health Organization Discontinued USRTK Food Industry Collection: US Right to Know, 2015. Available: https://www.industrydocuments. ucsf.edu/docs/kzkk0228

102 Harris S. Reminder for the Mid-Year ILSI Board of Trustees Conference Call - Thursday, July 9, 2015 USRTK Food Industry Collection: US Right to Know, 2015. Available: https://www. industrydocuments.ucsf.edu/docs/pjlk0228

103 Voûte J, Heughan A, Casimiro J. Non-Communicable diseases and the food and beverage industry. Lancet 2012;379:410-1.

104 Alexander E, Yach D, Mensah GA. Major multinational food and beverage companies and informal sector contributions to global food consumption: implications for nutrition policy. Global Health 2011;7:26.

105 Kadandale S, Marten R, Smith R. The palm oil industry and noncommunicable diseases. Bull World Health Organ 2019;97:118-28.

106 Goltzman M, Vermeulen W. [INFORM: 3-4 May BIAC Forum, Industry Organized OECD on Innovation in Health and Well-Being] DC Leaks Coca Cola Emails: DC Leaks, 2016. Available: https:// www.industrydocuments.ucsf.edu/docs/tjcl0226

107 Seitz K, Martens J. Philanthrolateralism: private funding and corporate influence in the United nations. Glob Policy 2017;8:46-50.

108 The Coca-Cola Company. 2019 Business \& Sustainability Report. Atlanta, GA: The Coca-Cola Company; 2020. https://www.cocacolacompany.com/content/dam/journey/us/en/reports/coca-colabusiness-and-sustainability-report-2019.pdf

109 PepsiCo. Annual report 2019. Harrison, NY: PepsiCo; 2020. https:// www.pepsico.com/docs/album/annual-reports/pepsico-inc-2019annual-report.pdf

110 Nestlé. 2019 annual review. Vevey: Nestlé; 2020. https://www. nestle.com/sites/default/files/2020-03/2019-annual-review-en.pdf

111 Project Last Mile. What we do, 2020. Available: https://web.archive. org/web/20201106160929/https://www.projectlastmile.com/whatwe-do/ [Accessed 6 Nov 2020].

112 World Health Organization. WHO welcomes industry action to align with global trans fat elimination targets, 2019. Available: https:// www.who.int/news-room/detail/07-05-2019-who-welcomesindustry-action-to-align-with-global-trans-fat-elimination-targets [Accessed 12 May 2021].

113 Ralston R, Hil SE, da Silva Gomes F, et al. Towards preventing and managing conflict of interest in nutrition policy? an analysis of submissions to a consultation on a draft who tool. Int $J$ Health Policy Manag 2020.

114 Clapp J, Scrinis G. Big food, Nutritionism, and corporate power. Globalizations 2017;14:578-95.

115 Food and Agriculture Organization. Evaluation of the FAO strategy for partnerships with civil society organizations. Rome: Food and Agriculture Organization; 2020. http://www.fao.org/3/nd866en/ nd866en.pdf

116 Nixon L, Mejia P, Cheyne A. "We're Part of the Solution": Evolution of the Food and Beverage Industry's Framing of Obesity Concerns Between 2000 and 2012. Am J Public Health.

117 Mialon M, Mialon J, Calixto Andrade G. 'We must have a sufficient level of profitability': food industry submissions to the French parliamentary inquiry on industrial food. Critical Public Health 2019:457-67.
118 Knai C, Petticrew M, Capewell S, et al. The case for developing a cohesive systems approach to research across unhealthy commodity industries. BMJ Glob Health 2021;6:e003543.

119 Maani N, McKee M, Petticrew M, et al. Corporate practices and the health of populations: a research and translational agenda. Lancet Public Health 2020;5:e80-1.

120 Moodie R, Stuckler D, Monteiro C, et al. Profits and pandemics: prevention of harmful effects of tobacco, alcohol, and ultraprocessed food and drink industries. Lancet 2013;381:670-9.

121 Brownell KD, Warner KE. The perils of ignoring history: big tobacco played dirty and millions died. How similar is big food? Milbank $Q$ 2009;87:259-94.

122 Grüning T, Weishaar H, Collin J, et al. Tobacco industry attempts to influence and use the German government to undermine the who framework convention on tobacco control. Tob Control 2012;21:30-8.

123 Gilmore AB, Savell E, Collin J. Public health, corporations and the new responsibility deal: promoting partnerships with vectors of disease? J Public Health 2011;33:2-4.

124 Maani N, Van Schalkwyk MC, Petticrew M, et al. The new WHO Foundation - global health deserves better. BMJ Glob Health 2021;6:e004950.

125 Collin J, Hill SE, Kandlik Eltanani M, et al. Can public health reconcile profits and pandemics? an analysis of attitudes to commercial sector engagement in health policy and research. PLOS One 2017; 12:e0182612.

126 Fooks GJ, Smith J, Lee K, et al. Controlling corporate influence in health policy making? An assessment of the implementation of article 5.3 of the World Health Organization framework convention on tobacco control. Global Health 2017;13:12.

127 Chung-Hall J, Craig L, Gravely S, et al. Impact of the WHO FCTC over the first decade: a global evidence review prepared for the impact assessment expert group. Tob Control 2019;28:s119-28.

128 Craig L, Fong GT, Chung-Hall J, et al. Impact of the WHO FCTC on tobacco control: perspectives from stakeholders in 12 countries. Tob Control 2019;28:s129-35.

129 Nestlé. COVID-19: Nestlé supports equitable vaccination through COVAX, 2021. Available: https://web.archive.org/web/ 20210407111217/https://www.nestle.com/media/news/covid-19nestle-supports-equitable-vaccination-covax [Accessed $7 \mathrm{Apr}$ 2021].

130 Jacobs A. In sweeping war on obesity, Chile slays Tony the tiger. The New York Times 2018 https://www.industrydocuments.ucsf. edu/docs/rpgm0229

131 Scrinis G. Reframing malnutrition in all its forms: a critique of the tripartite classification of malnutrition. Glob Food Sec 2020;26:100396.

132 World Health Organization. Double burden of malnutrition, 2019. Available: https://www.who.int/nutrition/double-burdenmalnutrition/en/ [Accessed 21 Aug 2019].

133 Hawkes C, Ruel MT, Salm L, et al. Double-duty actions: seizing programme and policy opportunities to address malnutrition in all its forms. Lancet 2020;395:142-55.

134 Maani N, VAN Schalkwyk MC, Petticrew M, et al. The commercial determinants of three contemporary national crises: how corporate practices intersect with the COVID-19 pandemic, economic Downturn, and racial inequity. Milbank Q 2021. doi:10.1111/14680009.12510. [Epub ahead of print: 30 Mar 2021].

135 World Health Organization. Global strategy for the prevention and control of noncommunicable diseases. Geneva: World Health Organization; 2000. https://apps.who.int/gb/archive/pdf_files/ WHA53/ea14.pdf

136 World Health Organization. Diet, nutrition and the prevention of chronic diseases: report of the joint WHO/FAO expert consultation. Geneva: World Health Organization; 2003. https://www.who.int/ dietphysicalactivity/publications/trs916/en/

137 World Health Organization. Process for a global strategy on diet, physical activity and health. Geneva: World Health Organization 2003. https://apps.who.int/iris/bitstream/handle/10665/67433/ WHO NMH EXR.02.2 Rev.1.pdf

138 World Health Organization. 2008-2013 action plan for the global strategy for the prevention and control of noncommunicable diseases. Geneva: World Health Organization; 2008. https://apps. who.int/iris/bitstream/handle/10665/44009/9789241597418_eng. pdf

139 World Health Organization. Set of recommendations on the marketing of foods and non-alcoholic beverages to children Geneva: World Health Organization; 2010. https://www.who.int/ dietphysicalactivity/publications/recsmarketing/en/

140 World Health Organization. WHO global Forum: addressing the challenge of noncommunicable diseases, 2011. Available: https:// 
www.who.int/nmh/events/global_forum_ncd/en/ [Accessed 7 Jul 2020].

141 World Health Organization. A framework for implementing the set of recommendations on the marketing of foods and non-alcoholic beverages to children. Geneva: World Health Organization; 2012. https://www.who.int/dietphysicalactivity/framework_marketing_ food to children/en/

142 Food and Agriculture Organization, World Health Organization. Second International Conference on nutrition outcome document: framework for action. Rome: Food and Agriculture Organization; 2014. http://www.fao.org/3/a-mm215e.pdf

143 World Health Organization. Second International Conference on nutrition outcome document: Rome Declaration on nutrition. Rome: Food and Agriculture Organization; 2014. http://www.fao.org/3/aml542e.pdf

144 Food and Agriculture Organization. ICN2 second International Conference on nutrition Rome, 2014. Available: http://www.fao.org/ about/meetings/icn2/en/ [Accessed 12 Jan 2021].

145 United Nations. Transforming our world: the 2030 agenda for sustainable development, 2015. Available: https://sustainabledeve opment.un.org/post2015/transformingourworld [Accessed 12 May 2021]

146 Jha A, Kickbusch I, Taylor P. Accelerating achievement of the sustainable development goals a game changer in global health. BMJ 2016;352:i409.

147 World Health Organization. Fiscal policies for diet and the prevention of noncommunicable diseases. Geneva: World Health Organization; 2016. https://www.who.int/dietphysicalactivity/ publications/fiscal-policies-diet-prevention/en/

148 Commission on Ending Childhood Obesity. Report of the Commission on ending childhood obesity. Geneva: World Health Organization; 2016. https://apps.who.int/iris/bitstream/handle/ 10665/204176/9789241510066_eng.pdf

149 World Health Organization. Montevideo roadmap 2018-2030 on NCDS as a sustainable development priority. Geneva: World Health Organization; 2017. https://www.who.int/conferences/global-ncdconference/Roadmap.pdf

150 World Health Organization. Tackling NCDs: 'Best buys' and other recommended interventions for the prevention and control of noncommunicable diseases. Geneva: World Health Organization; 2017. https://apps.who.int/iris/bitstream/handle/10665/259232/ WHO-NMH-NVI-17.9-eng.pdf

151 World Health Organization. Follow-up to the high-level meetings of the United Nations General Assembly on health-related issues: prevention and control of noncommunicable diseases. Geneva: World Health Organization; 2019. https://apps.who.int/gb/ebwha/ pdf_files/WHA72/A72_19-en.pdf

152 World Health Organization. WHO Independent high-level commission on noncommunicable diseases: final report: it's time to walk the talk. Geneva: World Health Organization; 2019. https:// apps.who.int/iris/handle/10665/330023
153 Briscoe A. Achievement for discussion during executive session Western sugar cooperative ADM litigation: center for science in the public interest, 2004. Available: https://www.industrydocuments. ucsf.edu/docs/htpj0226

154 Goltzman M, Vermeulen W. FW: inform: World health assembly may 23-28 DC leaks Coca Cola Emails: DC leaks, 2016. Available: https://www.industrydocuments.ucsf.edu/docs/kqcl0226

155 Dyer O. United States wins more time to Lobby against WHO diet plan. BMJ 2004;328:245-a-245

156 Cannon G. Why the bush administration and the global sugar industry are determined to demolish the 2004 WHO globa strategy on diet, physical activity and health. Public Health Nutr 2004;7:369-80.

157 Waxman HA. Politics of international health in the bush administration. Development 2004;47:24-8.

158 Brueggemeyer B. ILSI draft IRS form 990 for 2013 USRTK food industry collection: US right to know, 2014. Available: https://www. industrydocuments.ucsf.edu/docs/yqkk0228

159 Kearns CE, Watt RG. Transnational corporations and oral health: examples from the sugar industry. Community Dent Health 2019;36:157-62.

160 Powell K, Mackay D, Rosenfeld I. Re: a global commitment to action on the global strategy on diet, physical activity and health. letter from food and beverage CEOs to DR Margaret Chan, director general of the World Health Organization, 2008. São Paulo: Instituto Brasileiro de Defesa do Consumidor. Available: https:// web.archive.org/web/20101122194734/http://www.idec.org.br/ pdf/OMS_companies_commitment_WHO.pdf [Accessed 6 Nov 2020].

161 International Food and Beverage Alliance. About us, 2021. Available: https://web.archive.org/web/20210129184825/https:// ifballiance.org/about-us/ [Accessed 29 Jan 2021].

162 Landmark Public Affairs. Home page, 2020. Available: https://web. archive.org/web/20200822112750/http://landmarkpublicaffairs. com/ [Accessed 29 Aug 2020].

163 Landmark Public Policy Advisers Europe Ltd. Transparency register entry, 2020. European Commission. Available: https://ec.europa. eu/transparencyregister/public/consultation/displaylobbyist.do?id= 98945367035-89\&locale=en\#en [Accessed 23 Sep 2020].

164 FoodServiceEurope. Eu transparency register entry, 2021. European Commission. Available: https://ec.europa.eu/ transparencyregister/public/consultation/displaylobbyist.do?id= 822198744-40 [Accessed 7 Apr 2021].

165 Tobacco Control Research Group. Delon Human, 2020. Tobacco Tactics. Available: https://tobaccotactics.org/wiki/delon-human/ [Accessed 15 Oct 2020]

166 Nagarajan R. Leaked mail reveals lobbying by food, beverage giants to access policy making in who. Times of India 2015 https:// timesofindia.indiatimes.com/business/international-business/ leaked-mail-reveals-lobbying-by-food-beverage-giants-to-accesspolicy-making-in-who/articleshow/47361739.cms 